\title{
Music and Politics, Performance, and the Paradigm of Historical Contextualism
}

\section{CHRISTOPHER MOORE}

What are our goals when we teach a course like "Music and Politics" to a classroom comprised of performers? How can this historical approach help young performers in their quest to become better musicians? How are students to apply what they learn in such a course in their practical work as performers? Since 2007, a year during which I offered "Music and Politics" courses at two different institutions (the University of $\mathrm{X}$ and the University of $\mathrm{Y}$ ), these questions have been the forefront of my pedagogical reflections. I was thus naturally drawn to a trio of recent articles published in Music \& Politics in which Patricia Hall, Amy Beal, and Dard Neuman elaborate on their approaches to teaching this subject to a student clientele comprised primarily of non-majors. ${ }^{1}$ While this article follows in their footsteps by providing some practical suggestions regarding course content and in-class activities for "Music and Politics" courses, it also differs significantly from them in that it concentrates primarily on the challenges associated with offering "Music and Politics" to performance majors. In the process, it voices a critical and somewhat deconstructive argument by querying the current pedagogical paradigm through which interactions between music and politics are generally elucidated.

For present purposes I will call this pedagogical norm the "Paradigm of Historical Contextualism" (PHC). The PHC is implicitly structured and defended around the idea that the study of musical works in their historical contexts is an essential stepping stone for achieving authoritative musical understanding and that, equipped with such knowledge, students may become better musicians. ${ }^{2}$ Laudable though this goal may be, I argue that the PHC, based as it is upon the pervasive use of interpretive strategies that are conceived almost entirely without recourse to musical practice, constitutes a disciplinary deformation that erects barriers of understanding to performance students within the academy. Not only does the PHC consistently bolster the epistemological supremacy of musical knowledge over musical performance, it also denies performers the ability to derive a coherent discourse rooted in their musical practice. Ultimately, this article questions the methods of the PHC for the practical and professional musical needs of performance students and in so doing aims to stimulate further discussion regarding musicology's pedagogical agendas within the academy.

My argument builds upon a growing literature that has critiqued the ways in which the musicological community has centered its focus on musical works while concomitantly marginalizing or at

\footnotetext{
${ }^{1}$ Patricia Hall, "Music and Politics: A Class for Non-Majors," Music E Politics 1, no. 2 (2007); Amy Beal, "Music \& Politics in the Classroom: Politics and Protest in American Musical History," Music E Politics 1, no. 2 (2008); Dard Neuman, "Music, Politics, and Protest," Music E Politics 2, no. 2 (2008).

${ }^{2}$ Some might disagree by claiming that the goals that accompany the study of music history are more closely aligned with those (like the development of critical thought, cultural awareness, etc.) that structure the entire network of humanistic disciplines and, in this sense, have limited immediate use to performers. Yet, it would seem strange that music-history pedagogues would abdicate all responsibility with regards to the professional formation of musicians given the ostensibly common focus of both musicologists and musicians: that of music. This seems particularly true within music "departments" that offer conservatory-style training, or within music "schools" or "faculties" that offer academic instruction as an integral complement to professional training.
} 
times neglecting performance and the embodied knowledge of expert performers. As Dillon Parmer has recently argued, "musicologists are programmed from the outset of their academic deformation not only to suppress performing [...], but also to uphold as superior, as more prestigious, those forms of knowledge about music [...] which can be produced without any recourse to actual music making." David Gramit makes a similar point when he bemoans the way that standard music history curricula deal almost exclusively with composers and their works while neglecting to engage with performers, pedagogues, and performances as historical actors. He claims that this approach perpetuates a pedagogical system in which "practicing musicians are trained with the unstated goal that they will acquiesce to the disappearance of their practice behind the musical object." ${ }^{4}$ Both Gramit and Parmer assert that such a pedagogical mandate constructs scholarly reflection about music as superior to that of expert musical practice. To say it differently, these pedagogical approaches reaffirm that "meaning, not experience, is the academy's favourite coin." Carolyn Abbate has argued for a re-evaluation of the legitimacy of this musicological currency, particularly with regards to its discomfort in the face of the "huge, phenomenal explosion" that constitutes musical performance. ${ }^{6}$ She contends that interpretative models derived from hermeneutics and formalism are inadequate in dealing with the various manifestations of what Hans Ulrich Gumbrecht has labelled "presence culture," and of which live musical performance, as a result of its status as an embodied act of "self-unconcealment," constitutes a particularly cogent example. ${ }^{7}$ Parmer argues that the epistemological authority of the PHC and other forms of "technical rationality" have not only deflected scholarly interest away from live performance, they have also served to deny performers the possibility of developing discourses rooted in the musical practice of performing. ${ }^{8}$ In short, though we regularly say that so-and-so "knows how to play the piano," the highly specialized physical and mental processes that subtend this knowledge have been silenced as legitimate forms of musical knowledge within the context of the "hermeneutic maximalism" that dominates contemporary music research and pedagogy. ${ }^{9}$

Unsurprisingly, this musicological prejudice against performance identified by Abbate, Gramit, Parmer and others, has been at times explicitly voiced within the musicological literature. Boethius' claims concerning the supremacy of musical knowledge over that of musical practice constitutes just one of the most famous and oft-cited examples ("How much more admirable, then, is the science of music in apprehending by reason than in accomplishing by work and deed!"). ${ }^{10}$ But similar sentiments are also found much closer to home in the reflections of some of the most prominent musical thinkers of the

\footnotetext{
${ }^{3}$ Dillon R. Parmer, “Musicology as Epiphenomenon: Derivative Disciplinarity, Performing, and the Deconstruction of the Musical Work," repercussions (Spring 2007): 12.

${ }^{4}$ David Gramit, "Music Scholarship, Musical Practice and the Art of Listening," in Music and Marx: Ideas, Practice, Politics, ed. Regula Burckhardt Qureshi (New York, London: Routledge, 2002), 16.

${ }^{5}$ Karol Berger, "Musicology According to Don Giovanni, or: Should We Get Drastic?” The fournal of Musicology 22, no. 3 (2005), 496.

${ }^{6}$ Carolyn Abbate, “Music - Drastic or Gnostic," Critical Inquiry 30 (2004): 533.

${ }^{7}$ On "presence culture" see Hans Ulrich Gumbrecht, Production of Presence: What Meaning Cannot Convey (Stanford: Stanford University Press, 2004), 78-90 and passim. The primacy of formalist approaches applied to the study and appreciation of music was famously critiqued by Rose Rosengard Subotnik in her essay, "Toward a Deconstruction of Structural Listening: A Critique of Schoenberg, Adorno, and Stravinsky," in Deconstructive Variations: Music and Reason in Western Society (Minneapolis: University of Minnesota Press, 1996), 148-176. See the collection edited by Andrew Dell'Antonio, Beyond Structural Listening? Postmodern Modes of Hearing for varied responses to Subotnik's ideas (Berkeley and Los Angeles: University of California Press, 2004).

${ }^{8}$ On "technical rationality" see Donald Schön, The Reflective Practitioner: How Professionals Think in Action (London: Temple Smith, 1983).

${ }^{9}$ Hans Ulrich Gumbrecht, Production of Presence, 55.

${ }^{10}$ Cited in Oliver Strunk, Source Readings in Music History, ed. Leo Treitler (New York: Norton, 1998), 142.
} 
previous century. Manfred Bukofzer's position was unequivocal when he claimed that performers "do not know what they are doing, even though they may give "unconsciously" a creditable performance." 11 Joseph Kerman dismissed the knowledge set of performers as little more than an "arcane sign-gesture-and-grunt system." 12 Ostensibly mute and dumb, performers are "the doers, not the talkers." ${ }^{13}$ More recently, Leonard Meyer has stressed that performance does not necessarily "entail understanding." 14 Rather it must prop itself up with musicological scaffolding in order to achieve authoritative credibility. An extreme example of this position may be located in the writings of Theodor Adorno, who gave voice to a musicological ideal by describing authoritative performance-one which brings "hidden relationships" to the fore-as an act of "all-encompassing analytical consciousness." "Further examples of the "Analyst as Authoritarian" were especially visible in the late 1980s and early 1990s, in particular in the writings of Wallace Berry and Eugene Narmour, who offered up prescriptive interpretative formulations to the attention of analysis-savvy performers. ${ }^{16}$ Though the unidirectional "path from analysis to performance" pursued by Berry and others throughout the 1990s has since been critiqued by scholars like Nicolas Cook, Janet Schmalfeldt and Christopher Small, a cosy assumption still permeates music scholarship at large: that one of the primary roles of performance is to give "process" to the "products" of music research. ${ }^{17}$ Conceived thus, performers become mediators in a musical hierarchy that descends from composer and music scholar down to performer, and finally, listener.

In the discipline of musicology, this perspective hardened with the dramatic growth of the "authentic" performance movement around which developed, in the words of Richard Taruskin, a "modernist performance ethics" that serves "the idealization of the objectified work and [seeks] by the proscriptive use of research evidence to keep the threateningly contingent subjectivity of the performer at bay."18 Taruskin was certainly not the first to warn us of such things. Indeed, already back in 1945, pianist Artur Schnabel was cautioning American performance students against this modern performance paradigm, deriding it as a cowardly "safe conduct to wisdom, a trust in methods and books and rules to lead to the solution of problems, to settle everything." ${ }^{19}$ For him, the PHC constituted a form of intellectual

\footnotetext{
${ }^{11}$ Manfred Bukofzer, The Place of Musicology in American Institutions of Higher Learning (New York: The Liberal Arts Press, 1957), 24.

${ }^{12}$ Joseph Kerman, Contemplating Music (Cambridge: Harvard University Press, 1985), 196.

${ }^{13}$ Ibid.

${ }^{14}$ Leonard B. Meyer, Music, the Arts, and Ideas: Patterns and Predictions in Twentieth-Century Culture (Chicago: Chicago University Press, 1994), 291: "It is important to note that neither memorization nor performance necessarily entail understanding. Just as it is possible to learn to read, to memorize, and to recite (perform) a series of meaningless syllables or a text in a language one does not know, so it is possible to read, memorize, and perform music that one does not really understand."

${ }^{15}$ Theodor W. Adorno, "On the Problem of Musical Analysis," in Essays on Music, ed. Richard Leppert, translated by Susan H. Gillespie (Berkeley: University of California Press, 2002), 168.

${ }^{16}$ Janet Schmalfeldt, "Response to the 2004 SMT Special Session "Performance and Analysis: Views from Theory, Musicology, and Performance," Music Theory Online 11, no. 1 (2005), par 4. See also, Eugene Narmour, "On the Relationship of Analytical Theory to Performance and Interpretation," in Explorations in Music, the Arts, and Ideas: Essays in Honor of Leonard B. Meyer, ed. Eugene Narmour and Ruth Solie (Stuyvesant, NY, 1988), 317-40; Wallace Berry, Musical Structure and Performance (New Haven: Yale University Press, 1989).

${ }^{17}$ Nicholas Cook, "Between Process and Product: Music and/as Performance," Music Theory Online 7, no. 2 (2001).

${ }^{18}$ Richard Taruskin, "Last Thoughts First: Wherein the Author Gently Replies to a Few of His Critics and Takes Tender Leave of the Topic," in Text and Act: Essays on Music and Performance (New York, Oxford: Oxford University Press, 1995$), 23$.

${ }^{19}$ Artur Schanbel, My Life and Music (New York: Dover, 1988), 155. Emphasis in the original. Nicholas Cook echoed this sentiment in 2001 when criticising how the position of musicology within the performance practice movement resembled that of both "legislator and law enforcement officer." Nicholas Cook, "Between Process and Product: Music and/as Performance," Music Theory Online 7, no. 2 (2001), par. 4.
} 
tyranny that could not be trusted for artistic purposes because of the severe limits it places upon the artistic imagination in the creative processes of both composition and performance. ${ }^{20}$

\section{Cognitive Dissonances in the Classroom}

So described, this "modernist performance ethics," with its emphasis on the epistemological authority of text and context, may also be viewed as characterizing the ethics of contemporary musichistory pedagogy. Though current trends in musicology, particularly the turn towards cultural history, have considerably expanded the parameters through which we attempt to understand music, the PHC, despite its purported pedigree as an extension of the "new musicology," remains steadfastly attached to the production of intellectual, supra-audible meanings derived from the objectification of musical works. ${ }^{21}$ In such an environment, the contingent subjectivities of performers, including their ability to reflect on music from the standpoint of their practical expertise, are largely withheld. Writings on music history pedagogy confirm this trend: a recent collection of articles devoted to the subject is unanimously silent on how music-making might be integrated within the classroom or the way in which discourses about music might be constructed by drawing upon the experience of live performance. As this collection illustrates, whether in history courses designed for music "majors" specializing in performance or those crafted for non-majors and liberal arts students, the PHC reigns supreme. ${ }^{22}$

Judging solely from the evidence of their articles, Beal, Hall and Neuman's pedagogical approaches to "Music and Politics" appropriated both the methods and ethics of the PHC. To briefly summarize, these scholars sought to sensitize undergraduate students (not all of whom, admittedly, were music majors) to how musical works are influenced by "governmental systems," (Hall) how they "respond to political events," (Beal) and how they contain "underlying ideological implications" (Beal). In so doing, they drew on divergent repertories from throughout music history. Hall's course was broadly chronological and featured works ranging from the medieval motet to Berg's Wozzeck to 1990's rap. Beal's course marshalled a vast repertory of twentieth-century American works to illustrate her theme of "Politics and Protest in American Music History." Neuman's course weaved a narrative that migrated between American protest songs, Bengali cinema, and South Asian musical traditions to present a cross-cultural examination of music and its relationship to politics and protest.

Of course there is absolutely nothing wrong with any of that. Like countless music history courses offered throughout North America, theirs valorized that which constitutes the traditional and entirely laudable aims of humanistic studies in the academy: the development of critical thought, cultural awareness, linguistic skills, and literary techniques. Indeed, I readily admit that, like these courses of my colleagues, those that I offered in 2007 also faithfully enacted the methodological predispositions of the PHC. Indeed, how could they have not? As a junior professor of musicology looking to successfully

\footnotetext{
${ }^{20}$ Ibid., 148. Schnabel's position is made apparent in his discussion of "a review of a work of a contemporary composer," most likely Copland's Appalachian Spring. Schnabel ironized about the work being viewed as "genuine . . Appalachian music" when in fact many more geographical distinctions could be made, including the street and the floor of the building on which the piece was composed: "Certainly there must be a loftier, more elevated inspiration on the twentieth floor [...] than on the second." His point was that this type of research, though ostensibly aiming to refine our understanding of a work, also necessarily confines it, while all the time denying the importance of artistic imagination in the creative and interpretive process. See also Richard Taruskin, "The Pastness of the Present and the Presence of the Past," in Text and Act, 150.

${ }^{21}$ For a discussion that effectively unravels the epistemological links that bind the "old" to the "new" musicology see Giles Hooper, The Discourse of Musicology (Aldershot; Burlington, VT: Ashgate, 2006), 5-40.

${ }^{22}$ Mary Natvig, ed. Teaching Music History (Aldershot; Burlington, VT: Ashgate, 2002).
} 
integrate within professional academic culture I did an entirely reasonable thing. Like countless musicians who first learn their craft by "covering" the musical styles of their elders, I too sought to imitate the pedagogical methodologies and associated discourse to which I had been exposed during my academic apprenticeship. Thanks to my program of study (one which involved plenty of in-class observation and no little amount of osmotic receptivity), I felt I had learned the tricks of the pedagogical trade and thereby could effectively employ musicology's critical and technical languages while imparting to my students a sense of the discourse valued by my discipline.

Yet throughout my graduate studies I had also grown suspicious of how musicological discourse, despite its earnest claims to the contrary, was predicated on an implicit exclusion; one in which the "howto" knowledge of performance was quietly and systematically sacrificed at the high altar of authoritative historical contextualism. As a professional musician who was slowly migrating from the performance world to the musicological fold, the positions from which musicology conceived and construed its object of study seemed to me at times to verge on the extra-terrestrial. This distance, so alien from my own direct experience and understanding of music, was both fascinating and troubling. Though I have since embraced the exercise of thinking about music from myriad critical vantage points with great enthusiasm, it has been, at times, a daunting struggle to resolve the cognitive dissonance that so often separates a performer's duty to the present (through performing) with one's ostensible responsibility to the past (through the PHC). This dissonance, I have since discovered, is one that also prickles the performers sitting in the same classroom desks I occupied not so long ago.

Throughout 2007, in-class feedback and the inevitable ritual of the "course evaluation" were particularly helpful in bringing this dissonance to light. During my courses, and in keeping with the explicitly stated goals of the official course outlines, I aimed to sensitize students to both the implicit and explicit intrusions of politics on a number of different types of music from the late $18^{\text {th }}, 19^{\text {th }}$ and $20^{\text {th }}$ centuries. It was clear that this mode of inquiry had both its fans and its detractors. Those in favour felt that the course offered "helpful information in understanding a work" whereas those against insisted that the course was about "music and politics," and regretted that too much emphasis had been placed on the latter at the expense of the former. Ultimately (inevitably?), some students were not convinced that viewing music through a political lens was of any practical value to their work as musicians. Certainly Copland's implication within Popular Front culture, Ives' advocacy of "direct democracy," or the political subtext of the interwar aesthetic of the machine were interesting when viewed as topics of cultural history they argued, but how could the information gained by adopting this investigative angle effect in any meaningful way musical performances of these works? ${ }^{23}$

The standard musicological defence, I suppose, would be to claim that sensitivity to political contexts provides the performing artist with a more complete appreciation for the factors that lead to a host of compositional decisions, not least of which involve such salient musical elements as genre and style. Governments, ideologies, and institutions create (even in the best of times) a network of constraints

\footnotetext{
${ }^{23}$ Relevant readings include, Elizabeth B. Crist, "Aaron Copland and the Popular Front," Fournal of the American Musicological Society 56/3 (Summer 2003): 409-465; Judith Tick, "Charles Ives and the Politics of Direct Democracy," in Ives Studies, edited by Philip Lambert (Cambridge: Cambridge University Press, 2006), 133; Rodney J. Payton, "The Music of Futurism: Concerts and Polemics," The Musical Quarterly 62, no. 1 (1976): 25-45. Ellen Koskoff has written about similar resistances in the classroom, namely those facing the inclusion of ethnomusicological content within the context of a Baroque "survey" course. Ellen Koskoff, "What Do We Want To Teach When we Teach Music? One Apology, Two Short Trips, Three Ethical Dilemmas, and Eighty-Two Questions," in Rethinking Music, ed. Nicholas Cook and Mark Everist (Oxford, New York: Oxford University Press, 1999), 556-557.
} 
to which individuals, willingly or unwillingly, consciously or subconsciously, submit themselves. Indeed, it may be argued that the terms of artistic endeavour are largely defined by these parameters, ones over which an artist often has little or no control. Quite simply put, an artist can never be divorced from contemporary society. Even the oft-cited category of artistic alienation is predicated upon the existence of an antagonistic social relationship, not complete (and ultimately unattainable) isolation and autonomy from the political world.

But does this (admittedly simplified) argument effectively respond to the scepticism of these performers? After all, the acculturation derived from the study of various political contexts seems at best latent when viewed within the environment of split-second decisions and reflexes that inform real-time performance. Ultimately, our work as musicologists/pedagogues (particularly in the conservatory-style setting of the university music departments/schools/faculties in which I have worked and studied) is partly justified on the assumption that the development of critical listening skills in the classroom helps create better performers on the concert stage. Yet the ostensible links between classroom listening practices and successful performances are ambiguous at best. How does classroom attention to historical context and hermeneutic interpretation ultimately convert into mastery of an instrument and convincing interpretations on the concert stage? From my own experience as a performer I find it difficult to contemplate performing a work like Debussy's En blanc et noir, replete with the challenges of ornate ensemble work and infinitesimal gradations of pianistic colour, while simultaneously "informing" my actions with considerations about the composer's creative relationship with the propaganda machine of WWI France and the musical exigencies dictated by his own nationalist stance. ${ }^{24}$ And even if I could, I am even less certain that it would automatically amount to a "better" interpretation compared to one offered by a team of pianists entirely ignorant of these, and other musicological questions.

I understand that some may cringe at such resistance to cultural history in the music classroom, interpreting it as a tell-tale symptom of anti-intellectualism within the performance world, or even as an example of downright laziness. I would like to stress, however, that my aim is not to deny or marginalize the importance of the PHC, be it concerned with the interaction of music and politics or any other topic. At its very best, cultural historical approaches provide a repertory of hermeneutic tools that may focus the listening experience in new, different, exciting, even troubling ways. There is much good to be said for this, for any addition to the plurality of the musical experience and the opening of the mind to fresh ways of hearing should be commended. Yet it seems to me that listening (as taught in the history class) and performing (as learnt in the act of doing) are activities that share very little in common, and that our pedagogical efforts encourage the development of the former while often neglecting to mention how it could influence the latter. We too often forget that, whether comfortably seated in the luxurious warmth of the concert hall, or fighting the cold, hard pews of the neighbourhood church, a listener may scratch any hermeneutic itch at leisure. Expert and reasoned historical decoding; distracted and outrageous fantasies-all these exist within the purview and privilege of the listening subject. The performer, however, as the sole agent of this "drastic" event, approaches it from an entirely different point of view and

\footnotetext{
${ }^{24}$ For a discussion, see Jane F. Fulcher, The Composer as Intellectual: Music and Ideology in France 1914-1940 (New York: Oxford University Press, 2005), 56-58 where she comments (as others have before her) on Debussy's juxtaposition of Bach's Ein' feste Burg and La Marseillaise. Though undoubtedly resonant for any political interpretation of this work, the "allusion" to La Marseillaise (for this is no straightforward citation) is notoriously difficult to perceive in performance. Indeed, Jonathan Dunsby has recounted how an entire room-full of AMS members was unable to hear it. See his “The Poetry of Debussy's En blanc et noir," in Analytical Strategies and Musical Interpretation: Essays on Nineteenth-and Twentieth-Century Music, ed. Craig Avery and Mark Everist (Cambridge: Cambridge University Press, 1966), 164, fn. 28.
} 
with quite another set of constraints and exigencies. Engaged in the moment-to-moment reality of the present and caught in a struggle to impose music's unique temporality on time itself, can the performer truly afford to "take time out" to stare through similar hermeneutic windows, to allow the mind the luxury of historical musings or flights of fancy? Does this not place the performer at risk of falling off the highvoltage temporal tight-rope that she herself is, at every moment, responsible for creating?

Expert performers reflecting on the "drastic" moment of musical performance have stressed that it does not involve anything close to Adorno's "all-encompassing analytic consciousness." Daniel Barenboim (who is surely better equipped to speak to such issues), has pretty much claimed the opposite in his characterization of the mental processes of performance as a "kind of conscious naiveté."25 Indeed, while performing, performers attend not to history or fantasies, but rather to questions of immediate concern. Though they can never blot out the past, as Karol Berger has rightfully argued, nor is it at all clear that the remembered remnants of prior musicological or theoretical inquiry (which after all, constitutes just one aspect of any performer's past) will be engaged in the present. ${ }^{26}$ Whether it be during a performance of Debussy's En blanc et noir or any other work, musicians immerse themselves within a world of musical considerations and opportunities so rich and complex that-for them-the vagaries of historical contextualism and hermeneutic interpretation (along with everything else that constitutes a performer's "past") are necessarily placed in a state of abeyance. They cede to the "drastic" considerations that define the present. And these drastic considerations, it must be stressed, need not be solely conceived in terms of the intellect; as Elizabeth Le Guin has so eloquently described, the expert performer is perhaps less concerned with the mind than she is with the hic et nunc of sheer physicality in the creation of musical sound. ${ }^{27}$ Ultimately, performance cannot be reduced to the methodologies of the PHC and their application to the drastic moment, for that moment involves so much more than the harnessing of reason and understanding. As Barenboim argues, an ideal state for making music involves "allowing the fingers, the heart, the brain, the belly, to cooperate in an unpremeditated way." 28 Given such ideas, which stress the role of "subjective contingencies" in the musical act, it is little wonder that some performers feel frustrated when confronted with the intrinsic limitations of the PHC in the way it describes and conceptualizes musical experience.

\section{Searching for Common Ground}

All this is not to say that my classes were unsuccessful. Despite the epistemological problems discussed above, there were plenty of moments of reciprocal discovery and insight into a wide range of musical and extra-musical topics. At the University of X, where the course was open primarily to graduate students in performance, our inquiry focussed on the interaction of music and politics in four different countries-France, Germany, the Soviet Union, and the United States. Students were requested to prepare material in anticipation of each meeting, and every class featured a student presentation based on that week's theme. Inevitably, some topics elicited more interest than others, and served to me as an

\footnotetext{
${ }^{25}$ Daniel Barenboim, Everything is Connected: The Power of Music, ed. Elena Cheah (London: Weidenfeld \& Nicolson, 2008), 58.

${ }^{26}$ Karol Berger, “Musicology According to Don Giovanni, or: Should We Get Drastic?” The fournal of Musicology 22, no. 3 (2005): 497.

${ }^{27}$ Elisabeth Le Guin, Boccherini’s Body: An Essay in Carnal Musicology (Berkeley: University of California Press, 2006), 14-37.

${ }^{28}$ Barenboim, Everything is Connected, 58.
} 
indicator of how musicological debates concerning music and politics are deemed relevant within the performance community at large.

For example, the Shostakovich controversy (which most students appeared to be aware of, at least to some degree) prompted at times passionate discussion, stemming no doubt from the students' engagement with the composer's music in their own work as pianists, singers, conductors and orchestral musicians. Laurel Fay's evidence for questioning the authenticity of Alexander Volkov's "memoir" of Shostakovich, and the long-standing debate over the political content of Shostakovich's symphonies appeared to truly engage them. ${ }^{29}$ When reminded of the special circumstances surrounding Volkov's publication as well as of its key position within the Shostakovich bibliography (similar in this respect to A.F. Schindler's notoriously flawed biography of Beethoven), students became increasingly aware of the importance of musicological work committed to establishing the authenticity and veracity of historical "evidence."

Despite all the heated rhetoric that has surrounded this controversy and the pedagogical necessity of presenting it in a non-partisan manner, the Shostakovich debate offered an effective corpus of materials that allowed students to grasp how propaganda, politics, historiography, thematic analysis, and musicological discourse can all play powerful roles in shaping the meanings that are ascribed to musical works. It also provided students with concrete examples of how politics and the standard concert repertory collide (in Shostakovich's fifth and seventh symphonies, for example). In doing so, this topic functioned as a lightning rod for questions concerning the ideology underlying the concert-hall experience and the repertory performed within. (How do works and performance traditions lend legitimacy to political structures? How can the multiplicity of musical meanings be squashed by the dictates of ideology?) The airing of such questions, though they did not help students with regards to specific performance matters, hopefully convinced them that they are themselves implicated in a profession which, despite its frequent claims to neutrality, is in fact politically fraught.

Whereas the class at the University of $\mathrm{X}$ aimed to sensitize students to how works by a variety of composers (including Strauss, Satie, Milhaud, Pfitzner, Ives, Shostakovich, Stravinsky, Blitzstein and others) were influenced by the external world of politics, my primary goal at the University of Y was to invite students to appreciate how musical works could themselves be interpreted as creative experiments in the fictitious formation of politicized communities. Largely drawn from the world of opera, the repertory we studied was chosen to highlight political structures and movements (such as absolutism, revolution, socialism, totalitarianism and democracy) that form the social fabric of specific musical works. For example, Beethoven's Fidelio was probed to get to the heart of its political meaning: is it indeed a work that embodies a revolutionary ethos (most grippingly represented in Florestan's famous plea from the depths of tyranny's dungeon: “Gott! Welch' dunkel Hier!”); or rather, can the work's denouement be viewed as a glorification of the political status quo, or even, of political reaction (as in the opera's final scene, with its clamorous celebration of benevolent absolutism and joyous assertion of traditional gender roles) ? $^{30}$

This interpretative approach, which emphasized the idea of musical works as political agents, yielded observations that were somewhat more applicable to the performers in the classroom. Our examination of the politics of Wagner's Die Meistersinger von Nürnberg, for example, impressed upon students that decisions regarding vocal quality and articulation by singers playing the role of Sixtus Beckmesser ("Den Tag seh ich erscheinen" Act 2, Scene 6) could be helpful in highlighting or downplaying the debateable presence of

\footnotetext{
${ }^{29}$ Dimitri Shostakovich, Testimony: The Memoirs of Dmitri Shostakovich as related to and edited by Solomon Volkov, trans. Antonina W. Bouis (New York: Harper and Row, 1979).

${ }^{30}$ See Paul Robinson, "Fidelio and the French Revolution," Cambridge Opera fournal 3 (1991): 23-48.
} 
anti-Semitic overtones in this work. ${ }^{31}$ Those singers who take a "straight-up" approach to this aria through the use of natural tone production, rhythmic accuracy and emotional earnestness (such as Hermann Prey's interpretation under the baton of Horst Stein at Bayreuth) foreground elements, which, though not erasing the comic aspect of the character, lessen those which Barry Millington and others have characterized as "Jewish." 32 Millington's interpretation of Beckmesser's aria as a "wailing melismata" in "Jewish cantorial style" is much less convincing when the underlying technical issues associated with the awkward tessitura and rhythmic declamation are not exaggerated in performance. ${ }^{33}$ On the other hand, interpretations (such as that of Thomas Allen under James Levine at the Met) which tend to highlight these same musical difficulties (by making them heard, rather than artfully concealed) appear to support the Beckmesser as Jew thesis. ${ }^{34}$

Students were quick to point out, however, that visual elements, including costumes, staging, and even props (like the type of guitar/lute played by Beckmesser), could as easily influence our reactions here. In the Met version, Beckmesser wore a ceremonial costume and touted an elaborately decorated instrument, whereas the Beckmesser of the Bayreuth production donned the costume of a poet/intellectual, which was more stream-lined and topped by a French beret. Some students felt that these visual clues were perhaps even more helpful in framing the way we understand the character of Beckmesser when compared with the types of "hidden" musical relationships that Millington has uncovered through textual analysis and by positioning the score (as opposed to individual performances) as the primary locus of musical meaning. Ultimately they were not convinced that the "music itself" nor any particular vocal technique, were potent enough signifiers to buttress a "Beckmesser as Jew" interpretation. Though they conceded that Millington's comparison of Beckmesser's aria with contemporaneous transcriptions of cantorial declamation looks handsome enough on the page, they felt that his acontextual musical analysis is severely weakened when the realities and contingencies of operatic performance are considered, be they from Wagner's time or from our own.

\section{Suggestions, Compromises, Solutions}

It became apparent that, more than any other genre, operatic performance was directly implicated by questions concerning the political content of musical works. This extended not only to the expressive delineation of character and chorus, but also, as we have seen, to questions of staging and mise-en-scène. Beyond opera and texted music in general, however, it was much more difficult to establish how readings of music's political messages (ostensibly embedded in a host of works on each course's program of study, from Gossec's Marche lugubre, to Pfitzner's Palestrina to Penderecki's Threnody to the Victims of Hiroshima) could have a quantifiable influence on performance. Nor did the study of political contexts in the common-practice repertory provide much for performers to consider in terms of "authentic" performance considerations: one would hardly wish to replicate the political context surrounding Olivier Messiaen's Quatuor pour la fin du temps, for example, as a way of constructing a cachet of historical authenticity in

\footnotetext{
${ }^{31}$ See for example, Barry Millington, "Nuremburg Trail: Is There Anti-Semitism in Die Meistersinger," Cambridge Opera Fournal 3 (1990): 39-62; Hans Vegt, "Sixtus Beckmesser: A Jew in the Brambles?" Opera Quarterly 12 (1995): 35-45.

${ }^{32}$ Richard Wagner, Die Meistersinger von Nürnberg, conducted by Horst Stein (Hamburg: Deutsche Grammophon: Distributed by Universal Music \& Video Distribution Corp., 2006).

${ }^{33}$ Millington, "Nuremburg Trail,"52.

${ }^{34}$ Richard Wagner, Die Meistersinger von Nürnberg, conducted by James Levine (Hamburg: Deutsche Grammophon ; New York, NY: Distributed by Universal Music \& Video Distribution Corp., 2004).
} 
performance. In short, when viewed then from a performance standpoint, the employment of pedagogical methods derived from the PHC was not particularly illuminating in these Music and Politics courses.

How then, apart from admirably attempting to "combat political complacency and historical ignorance," can instruction in Music and Politics find a way into the practice-room, or better yet, back into the "real" world from which this music emanated ${ }^{35}$ Certainly, encouraging performances related to course content graded on par with written assignments is an option that must be considered, even if it takes time away from traditionally-evaluated academic skills. Class-room performance is a way of bringing course content alive: what better ways to study French revolutionary song or the political marches of Hanns Eisler than by having students perform them? After all, listening to recorded renditions of these types of "obvious" political works can at times be a tedious, even depressing exercise. Emanating from the speakers at the front of the classroom, this music easily falls flat, somehow stripped of its élan due to the objectifying tendencies that accompany its mediated transmission. To make matters worse, those performances that make their way onto commercial recordings often do little justice to the political intensity and the exciting messiness that informed their creation. Concerned with conforming to existing paradigms of taste, contemporary recordings of political song are often fastidious, selfconscious, and overly refined.

Hector Berlioz, for one, recognized that these types of works called for something else, something that could only be brought forth through true political engagement and conviction. Recalling his participation in the July Revolution of 1830 he wrote that "at the sight of this enormous mass of people, I remembered that I had just arranged Rouget de Lisle's song [La Marseillaise] for orchestra and double choir, and that, rather than the words: 'tenors, basses' I had indicated in the score: Everything that has a voice, a heart and blood in its veins." ${ }^{36}$ To understand the fervour and political agency of such music, performances must not seek to be "beautiful," rather they must be grounded in a sense of total conviction, one that is not afraid to be worn on the sleeve, stained by the realities of the world though it may be. ${ }^{37}$

Students may find it difficult, however, to be passionate about singing Rouget de Lisle as a means of overthrowing the French Bourbon King, Charles X. More effective, perhaps, would be to invite students to reflect on current political issues by having them set new texts to pre-existent political songs in a creative form of contrafacta. In doing so, they would be participating in an age-old tradition involving the musical transmission of political messages, and one that offers plenty of opportunity for satire, subversion, and political critique. In fact, students need not feel obliged to remain confined to an explicitly political repertory. It would be interesting to observe how ostensibly "apolitical” works drawn from the standard repertory (a Schubert Lied, for example) could be modified in performance to reflect a contemporary political concern. By engaging in this process students would be encouraged not only to clarify aspects of their own political thinking, they would also learn valuable lessons about musical style and text-setting.

\footnotetext{
${ }^{35}$ Amy Beal, "Politics and Protest in American Music History," Music and Politics 2, no. 1 (Winter, 2008).

${ }^{36}$ Hector Berlioz, Mémoires (Paris: Flammarion, 1991), 156. “À la vue de cet immense concours de peuple, je m’étais rappelé que je venais d'arranger le chant de Rouget de Lisle à grand orchestra et à double chœur, et qu'au lieu de ces mots: ténors, basses, j'avais écrit à la tablature de la partition : Tout ce qui a une voix, un cœur et du sang dans les veines."

${ }^{37}$ Interestingly, this type of conviction is more likely to be found elsewhere than on a musical compact disc. Take for example Michael Curtiz's 1942 film, Casablanca. Here, the transient Europeans who have converged upon Rick's "Café Américain” chant La Marseillaise as a way of drowning out Die Wacht am Rhein as sung by a group of Nazi officers. This spontaneous, collective, and indignant act of music making embodies the conviction - tears, warts and all - that lies at the conceptual heart of these political works.
} 
Even more intriguing would be to have performers approach a work from their repertory with the intent of making its historically-determined political content manifest through performance. Here, many would no doubt feel compelled to experiment with non-traditional modes of performance as they begin to understand how the concert-hall-style delivery of musical works tends to eradicate the expression of any ideology that does not adhere to the persistent myth of musical autonomy. For example, how indeed can a pianist make an audience aware of the political context that weighed upon Debussy at the time of the composition of En blanc et noir? To do so convincingly would require a truly interdisciplinary effort, one that is dependant less on the written authority of bibliography and citation, than upon the creative juxtaposition of sound, text and image in a theatrical setting. No mere lecture-recital, such performances would involve the subjective interplay of artistically combined elements. Much closer to the premises of intermedia performance art, musical performance would here find itself entirely transformed through its imaginative engagement with the intertextual networks that underpin cultural history.

Finally, I propose that performers be invited-strongly encouraged, even-to critique the musicological literature that underscores any "Music and Politics" class by observing precisely how it fails to serve their needs in their quest to become professional musicians. Once again, I say this not to condemn the extraordinary and exciting work that is taking place in this field. Rather, I encourage it as a means by which performers can come to develop critical voices of their own, voices that formulate a discourse derived not from their skills as critical listeners, but from their expertise as music practitioners. Indeed, what better way to animate a "Music and Politics" course than to acknowledge and confront the epistemological conflict that so often divides musicology from music-making in the academy? For those who may worry about the broader relevance of musicology beyond the confines of the discipline itself, and for those performers looking to imaginatively break with the entrenched conventions of contemporary musical performance, such a process may represent a (modest) way out of an age-old dilemma that is as relevant as ever. ${ }^{38}$

\footnotetext{
${ }^{38}$ See for example, Philip V. Bohlman, "Musicology as Political Act," The Fournal of Musicology 11, no. 4 (1993): 411-436; Ralph P. Locke, "Musicology and/as Social Concern: Imagining the Relevant Musicologist," in Rethinking Music, ed. Nicholas Cook and Mark Everist (Oxford: Oxford University Press, 1999), 499-530.
} 